\title{
Morphology about the varieties mexican pomegranate fruit (Punica granatum) and its ripening stage
}

\author{
Jesús Alberto CORONADO-REYES ${ }^{1}$, Javier TINOCO-SALAZAR ${ }^{1}$, María Lizeth GUISA-MORALES ${ }^{1}$, \\ Consuelo de Jesús CORTÉS-PENAGOS², Juan Carlos GONZÁLEZ-HERNÁNDEZ ${ }^{1 *}$
}

\begin{abstract}
The pomegranate (Punica granatum) is a bush with abundant foliage originating from Iran, it was brought to Mexico during the time of the conquest and whose main characteristic is the fruit it generates, which is a big, globose berry with thick, shiny skin of red, green or yellow colour depending on the specie of pomegranate and the ripening stage in which itis founding. Recent research has shown that pomegranate contains chemical compounds with antioxidant and bactericidal activities resulting from its secondary metabolism as what are mainly polyphenols, terpenes and alkaloids, which affect the specific concentration of the state of maturity of the product and where most of them, polyphenolic compounds, are found in large quantities at this stage, presenting antioxidant activity and bactericide. The present article has the objective to analyse the ripening stage of three varieties of mexican pomegranate (Wonderful, Apaseo and Tecozautla) through a physicochemical characterization for which the morphology (sizes, colours and hardness) was analyzed as the amount of total suspended solids, $\mathrm{pH}$ and titratable acidity in the juice of the product to finish with the determination of the concentration of polyphenolic compounds with possible antioxidant and bactericide activity.
\end{abstract}

Keywords: Punica granatum; pomegranate; ripening; polyphenols.

Practical Application: With the morphological characterization of the mexican pomegranate it is possible to establish the point at which it can be consumed since, together with the physical and chemical characterization, the highest nutrient production would be obtained.

\section{Introduction}

Pomegranate (Punica granatum) belongs to the Punicaceae family and is a plant native to Iran (Sarkhosh et al., 2006). The pomegranate is considered a shrub, which has abundant foliage, a height around $5 \mathrm{~m}$, which generally adapts to Mediterranean climates. The leaves are green, elongated. The flower is flared and consists of 5 to 8 bright orange petals (Al-Maiman \& Ahmad, 2002).

Speaking of the cultivation of pomegranate worldwide, it is possible to mention that it is led by India, with an area of 100,000 hectares destined for the practice. Spain is the leading country in production in the European Union with an area of 2,325 hectares and a production of 27,389 tons. In America, the country with the highest production is the United States, followed by Chile and Peru and Mexico occupying third place (López-Mejía et al., 2010). In Mexico, the area devoted to pomegranate plantations is minimal and its consumption is not common compared to other fruits. In 2013, the production of pomegranate was around 4,400 tons obtained from approximately 630 hectares, being the states of Oaxaca, Hidalgo and Guanajuato the main producers, which contributed $77 \%$ of the national production. For the year 2014, there was a production of $4,773.98$ tons, which represented an increase of $8.5 \%$. For the year 2017 , a production of $6,816.22$ tons was registered, increasing production by $43 \%$; Now leading the ranking of main producers the states of Morelos, Oaxaca and Hidalgo. Michoacán does not appear among the first places in pomegranate production, but it is a fruit that is generated in the state; Therefore, knowing more information about the pomegranate and its cultivation can increase annual production, as has happened in other states (Servicio de Información Agroalimentaria y Pesquera, 2017). The increase in the production of the fruit brings with it an increase in the generation of derived products as well as an increase in the waste resulting from its processing, among which, the main waste is the peel, which represents approximately $50 \%$ of the weight. total of the fruit and to which a utility is not given and that, if not handled correctly, can mean a significant environmental problem. That is why it is important to propose management alternatives for this waste and its use.

Regarding about the chemically, pomegranate is made up of chemical compounds that result from its metabolism, either primary or secondary, receiving the name of metabolites. A primary metabolite is one that a plant synthesizes and uses to develop, grow and reproduce; whose molecular weight is high (Díaz, 2009). Among the primary metabolites are: carbohydrates, proteins, lipids, nucleic acids, vitamins and structural polymers; Like cellulose. On the other hand, a secondary metabolite usually 
has a low molecular weight and participates in the process of adaptation of the plant, as well as in the symbiosis with other organisms and in the attraction of pollinating insects for the dispersion of seeds and fruits (Sepúlveda-Jiménez, 2003). Secondary metabolites are considered as defense compounds and among them are polyphenols, terpenes, alkaloids, latex, gums and waxes (Vilela et al., 2011); however, because chemical analyzes in foods are usually based on primary metabolites, due to their high nutritional value, secondary metabolites are used to make functional biotechnological products. Chemical and physical analyzes of the fruit of the pomegranate have been reported by dividing them into three fractions, characterizing the compounds present in the peel, seed and arils. Of the total weight of the pomegranate fruit, about $40 \%$ of the weight corresponds to the aryls, which contains $85 \%$ of water, $10 \%$ of total sugars such as glucose, fructose and sucrose mainly, $1.5 \%$ of the weight corresponds to pectins, 0.2 to $1 \%$ are polyphenolic compounds, and the rest a mixture of organic acids, minerals such as calcium, magnesium, sodium, potassium, zinc, and cobalt, and other products of the secondary metabolism of the plant. The seeds contained in the aryls represent $10 \%$ of the total weight of the fruit, where, from 12 to $20 \%$ it is constituted by oils, of which, $80 \%$ corresponds to conjugated fatty acids with high contents in cis 9 , trans configuration 11 and cis 13, such as punic acid and linoleic acid. The fatty acids of the seeds constitute $95 \%$ of the oil, of them, $99 \%$ are triacylglycerols, the rest that make up the oil are: sterols, steroids, tocopherols and some cerebrosides. The other compounds that make up the total weight of the seed are lignins, protein, raw fiber, sugars, some vitamins, minerals, pectins, phytoestrogens such as comestrol and some polyphenols and terpenes (Sai \& Prakash, 2011). Finally, the pomegranate peel represents $50 \%$ of the total weight of the fruit and in it you can find some polyphenolic compounds such as: elagitannins, proanthocyanins, as well as alkaloid and glycoside compounds (Viuda-Martos et al., 2010). Polyphenols and terpenes, are the most abundant chemical compounds in nature. It has been observed that the polyphenols contained in pomegranate juice have an antioxidant effect depending on the ripening stage (Tezcan et al., 2009) so it is important to evaluate the polyphenols concentration in a ripening stage of the fruit and, to advantage the peel, to extract them and determining antioxidant and bactericide.

\section{Materials and methods}

\subsection{Vegetable material}

Three varieties of pomegranate in ripening coming from the states of Hidalgo and Guanajuato were analized. The varieties were: Wonderful, Apaseo and Tecozautla harvested in August of the years 2017 and 2018 where in this time is when pomegranate fruit is collected in Mexico (June-September). Samples was obtained to evaluate the degree of ripening and physicochemical characterization was made with the objective of estimate the ripening state of the non-climacteric fruit since there is not norms about its parameters. The parameters measured were the following.

\subsection{Physical parameters}

Size

The representative weight fruit of each varieties was expressed in grams. Subsequently, the equatorial and longitudinal diameters were measured and expressed in centimeters. The longitudinal diameter was measured partially and totally way, where, the total diameter included the crown or calyx of the fruit and the partial longitudinal diameter did not include it. Finally, the peel thickness was measured with a Vernier and the results expressed in $\mathrm{mm}$.

\section{Colour}

This parameter was measured with a ColorFlex to obtain the coordinates of the CIE colour system (for the acronym in English of the Commission Internationale de l'Éclairage), was calculated $\mathrm{L}^{*} \mathrm{a}^{*} \mathrm{~b}^{*}$ coordinates where the brightness is representing with the $\mathrm{L}^{*}$ coordinate, green tones for negative values with the $\mathrm{a}^{*}$ coordinate and yellow tones for positive values with the $b^{*}$ coordinate.

\section{Hardness}

This parameter was measured with a TA-XT2i texturometer where a deformation of $3 \mathrm{~mm}$ was made to the fruit, following the internal manual for hardness determination of green and ripening guava of the Biotechnology Laboratory of the Faculty of Chemistry Pharmacobiology of the Universidad Michoacana de San Nicolás de Hidalgo. Hardness is an important parameter because depending of the force applied to the fruit, it reflects the ripening, if the force applied is less the ripening was completed but if the force applied is mayor the ripening is early. The results were expressed as force applied to the fruit in Newtons $(\mathrm{N})$.

\section{Chemical parameters}

The $\mathrm{pH}$ was measured with a HANNA potentiometer (HI5222-02), the total soluble solids were measured to the juice extracted from each fruit with an $\mathrm{ABB}$ refractometer expressed in ${ }^{\circ}$ Brix, the titratable acidity was measured to the juice and were expressed the results as citric acid concentration $(\mathrm{mg} / \mathrm{ml})$ following mexicans norms (NMX-F-102-S-1978).

\section{Poliphenols determination}

The concentration of polyphenols was determined in peel of the different varieties of pomegranate to assess whether there were considerable concentrations of these metabolites in it so that they could be used in future research as chemical compounds with antioxidant and even bactericide activity. The extraction was carried out by liquid-solid extraction methods and the determination was carried out by the Folin-Ciocalteu method.

\section{Results and discussion}

\subsection{Ripening fruit stage}

\section{Physical parameters}

The weight between the species analyzed in 2017 and 2018 is presented at the end of the work in Table 1 and 2 with which 
it can be seen that it was similar only for the Wonderful and Apaseo varieties ( $405.36 \pm 34.1 \mathrm{~g}$ and $460 \pm 50.49 \mathrm{~g}$ respectively). The Tecozautla variety being the one with the lowest weight $(95.99 \pm 5.17 \mathrm{~g})$ because it had a shorter period of cultivation and was considered as partially green fruit since, based on comparisons of other pomegranates and growing conditions, the weights oscillate above $250 \mathrm{~g}$; however, for the year 2018 (Table 1) the physical parameters were similar.

The uniform behavior in the physiology of the fruits of the 2018 harvest is due to the fact that on this occasion there was a greater control in the collection so that, as what was sought was the verification of optimal points calculated with the 2017 harvest for extraction of polyphenols, said physiological variation did not have an effect on the concentration and activity of the metabolites of interest. Moreover was observed that at the time of drying the peel, a longer time was taken because there was a greater area through which the water had to be transferred in addition to containing a greater mesocarp amount of the segments causing a greater work in the drying since this vegetable part acts as moisture reserves reducing the loss of water, so they must be removed (Mercado et al., 2011). According to the hardness (Table 2), for the 2018 harvest in comparison with 2017 harvest where the hardness was smaller and the drying was carried out best for storage at room temperature, free of moisture and protected from light.

Compared the 2017 and 2018 harvests with other works where the physical changes that the fruit of the pomegranate has during its ripening process were monitored once the "set fruit" or the mooring of the fruit it can be established that the fruits of the Wonderful and Apaseo variety of the 2017 harvest have a maturity greater than 140 days (4 and a half months) after the fruit is tied; however, the Tecozautla variety has an approximate

Table 1. Different weighs of mexican pomegranate varieties (P. granatum). The data analized have a significance value $(\alpha)$ of 0.05 and are expressed as the mean \pm standard deviation, $\mathrm{n}=10$.

\begin{tabular}{lcc}
\hline \multirow{2}{*}{ Variety } & \multicolumn{2}{c}{ Weigh $(\mathrm{g})$} \\
\cline { 2 - 3 } & 2017 harvest & 2018 harvest \\
\hline Wonderful & $405.36 \pm 34.1$ a & $294.18 \pm 55.40 \mathrm{a}$ \\
Apaseo & $460.85 \pm 50.49$ a & $317.99 \pm 63.54 \mathrm{a}$ \\
Tecozautla & $95.99 \pm 5.17$ b & $286.01 \pm 29.34 \mathrm{a}$ \\
\hline
\end{tabular}

The $\mathrm{a}$ and $\mathrm{b}$ values are similarities between medias analized. maturity of 30 days; which is why that variety was the smallest (Yasoubi et al., 2007). For the attributes of the 2018 harvest, a uniform development was observed in the three varieties, as well as a similar maturation time, having an approximate development of 140 days after the set fruit.

For hardness could be observed that Apaseo variety in 2017 was the one with the highest resistance to deformation being $65.06 \pm 6.19 \mathrm{~N}$ followed by the Wonderful variety with $47.91 \pm 3.83 \mathrm{~N}$ and finally the Tecozautla variety with $39.45 \pm 11.35$ $\mathrm{N}$ being the latter is smaller than the rest because during transport to Morelia it had a visible softening with the humidity of the medium. For the year 2018 the hardness were of; Wonderful $34.61 \pm 9.071 \mathrm{~N}$, Apaseo $61.94 \pm 13.83 \mathrm{~N}$ and Tecozautla of $43.22 \pm 7.7 \mathrm{~N}$, a decrease being appreciable which reaffirms what is observed in the colour of the husks since a decrease in the deformation resistance of the fruits translates to a softening of the cell walls of the fruits by effect of the metabolic enzymes that are activated as a fruit matures.

The hardness in Table 3 a decrease being appreciable which reaffirms what is observed in the colour of the husks since a decrease in the deformation resistance of the fruits translates to a softening of the cell walls of the fruits by effect of the metabolic enzymes that are activated as a fruit matures. Based on the literature it is possible to establish that, for Mexican varieties, as a parameter of maturity control, a resistance to deformation can be taken as a reference in a range of 40 to $50 \mathrm{~N}$ (López-Rubira et al., 2017). In general, the softening of the fruit is a process of modifications in the structure of the cell wall where depolymerization of glycans and solubilization of pectin, and where enzymes such as polygalacturonase (PG), pectinmethylesterase (PME), endo-1,4- are involved $\beta$-glucanase, $\alpha$-arabinosidase and $\beta$-galactosidase among others. The activity of these enzymes during maturation is related to a change in cell wall polysaccharides; The time and moment of activity varies between enzymes (Brummell et al., 2004). Similarly, it has been observed that the action of pectinmethylesterasecatalyzes the desterification of the carboxyl group of polygalacturonic acid and increases the susceptibility of pectins to polygalacturonase (Sanchez et al., 1996).

With the results obtained and what is observed in the bibliography, it is possible to establish that the ripe fruits will have to be in a range of $40 \mathrm{~N}$ to $50 \mathrm{~N}$ depending on the variety, where said variation and loss of firmness is due to the process of modifications in the cell wall structure, both chemical and enzymatic (Brummell et al., 2004).

Table 2. Phisiology of mexican pomegranate fruit (P. granatum). The data analized have a significance value ( $\alpha$ ) of 0.05 and are expressed as the mean \pm standard deviation, $\mathrm{n}=10$.

\begin{tabular}{|c|c|c|c|c|c|c|}
\hline \multirow{2}{*}{ Variety } & \multicolumn{2}{|c|}{ Ecuatorial diameter $(\mathrm{cm})$} & \multicolumn{2}{|c|}{ Parcial longitudinal diameter $(\mathrm{cm})$} & \multicolumn{2}{|c|}{ Total longitudinal diameter $(\mathrm{cm})$} \\
\hline & 2017 harvest & 2018 harvest & 2017 harvest & 2018 harvest & 2017 harvest & 2018 harvest \\
\hline Wonderful & $9.01 \pm 0.2 \mathrm{a}$ & $8.31 \pm 0.58 \mathrm{a}$ & $8.55 \pm 0.16 \mathrm{a}$ & $7.63 \pm 0.53 a$ & $10.28 \pm 0.48 \mathrm{a}$ & $8.7 \pm 0.68 \mathrm{a}$ \\
\hline Tecozautla & $7.95 \pm 0.43 b$ & $8.3 \pm 0.43 \mathrm{a}$ & $6.91 \pm 0.41 b$ & $7.53 \pm 0.43 a$ & $8.77 \pm 0.17 b$ & $8.62 \pm 0.45 a$ \\
\hline
\end{tabular}

The a and $\mathrm{b}$ values are similarities between medias analized. 
The colour measure, the calculation of the hue angle of each of the tones presented by the fruit peel was made in the Figure 1 where, for the Wonderful variety there was an angle of $31.48^{\circ}$ and $26.11^{\circ}$ for the years 2017 and 2018 respectively belonging to the range of the reddish colours and where the decrease in angle indicates that there was a greater synthesis of metabolites in the peel which serve the fruit as a defence; These metabolites are mostly polyphenols and may indicate a slight increase in the ripening period. For the Apaseo variety there was an angle of $67.63^{\circ}$ hue and $76.62^{\circ}$ hue belonging to the range of green-yellow colours; and for the Tecozautla variety, there was a $24.02^{\circ}$ hue angle typical of the reddish-coloured bed and $59.6^{\circ}$ hue in the range of red-yellow colours for 2017 and 2018 respectively, where

Table 3. Hardness peel of different mexican pomegranate varieties ( $P$. granatum). The data analized have a significance value $(\alpha)$ of 0.05 and are expressed as the mean \pm standard deviation, $\mathrm{n}=10$.

\begin{tabular}{lcl}
\hline \multirow{2}{*}{ Variety } & \multicolumn{2}{c}{$\operatorname{Hardness}(\mathrm{N})$} \\
\cline { 2 - 3 } & 2017 harvest & 2018 harvest \\
\hline Wonderful & $3.2 \pm 0.3 \mathrm{~b}$ & $2.01 \pm 0.96 \mathrm{ab}$ \\
Apaseo & $3.2 \pm 0.2 \mathrm{~b}$ & $1.77 \pm 0.41 \mathrm{~b}$ \\
Tecozautla & $4.7 \pm 0.3 \mathrm{a}$ & $2.71 \pm 0.76 \mathrm{a}$ \\
\hline
\end{tabular}

The $\mathrm{a}$ and $\mathrm{b}$ values are similarities between medias medias analized. this increase is also explained in the phenomenon happened in the Wonderful variety. On the other hand, the characterization (Table 1 and 2) managed to corroborate the type of variety worked, since the Wonderfulvariety has as its main characteristic a reddish coloration in its peel, the Apaseo variety green-yellow coloration and the variety Tecozautla a yellow-reddish coloration once maturation is reached which occurs around 120 days after the flower of the pomegranate tree is fertilized and the development of embryos in the seeds begins.

\subsection{Chemical parameters}

Regarding with the Table 4, the $\mathrm{pH}$ in 2017 harvest, the Wonderfulvariety had a value of $1.17 \pm 0.23$, Apaseo was $1.37 \pm 0.08$ and Tecozautla was $3.37 \pm 0.06$, in the case of acidic fruits which had a concentration of $0.19 \pm 0.05 \mathrm{mg} / \mathrm{ml}$ of citric acid, $0.04 \pm 0.002 \mathrm{mg} / \mathrm{ml}$ of citric acid and $0.31 \pm 0.05 \mathrm{mg} / \mathrm{ml}$ of citric acid respectively which explains the decrease in the $\mathrm{pH}$ of the first two varieties. For the 2018 harvest the $\mathrm{pH}$ was; Wonderful $3.18 \pm 0.5$, Apaseo of $3.05 \pm 0.6$ and Tecozautla $3.7 \pm 0.2$ which show a greater uniformity with a concentration of citric acid for Wonderful of $0.13 \pm 0.05 \mathrm{mg} / \mathrm{ml}$, Apaseo of $0.04 \pm 0.005 \mathrm{mg} / \mathrm{ml}$ and Tecozautla of $0.05 \pm 0.04 \mathrm{mg} / \mathrm{mL}$ when compared with other mature varieties of pomegranate are close by what can be deferred that the fruits if they reached the state of maturation.

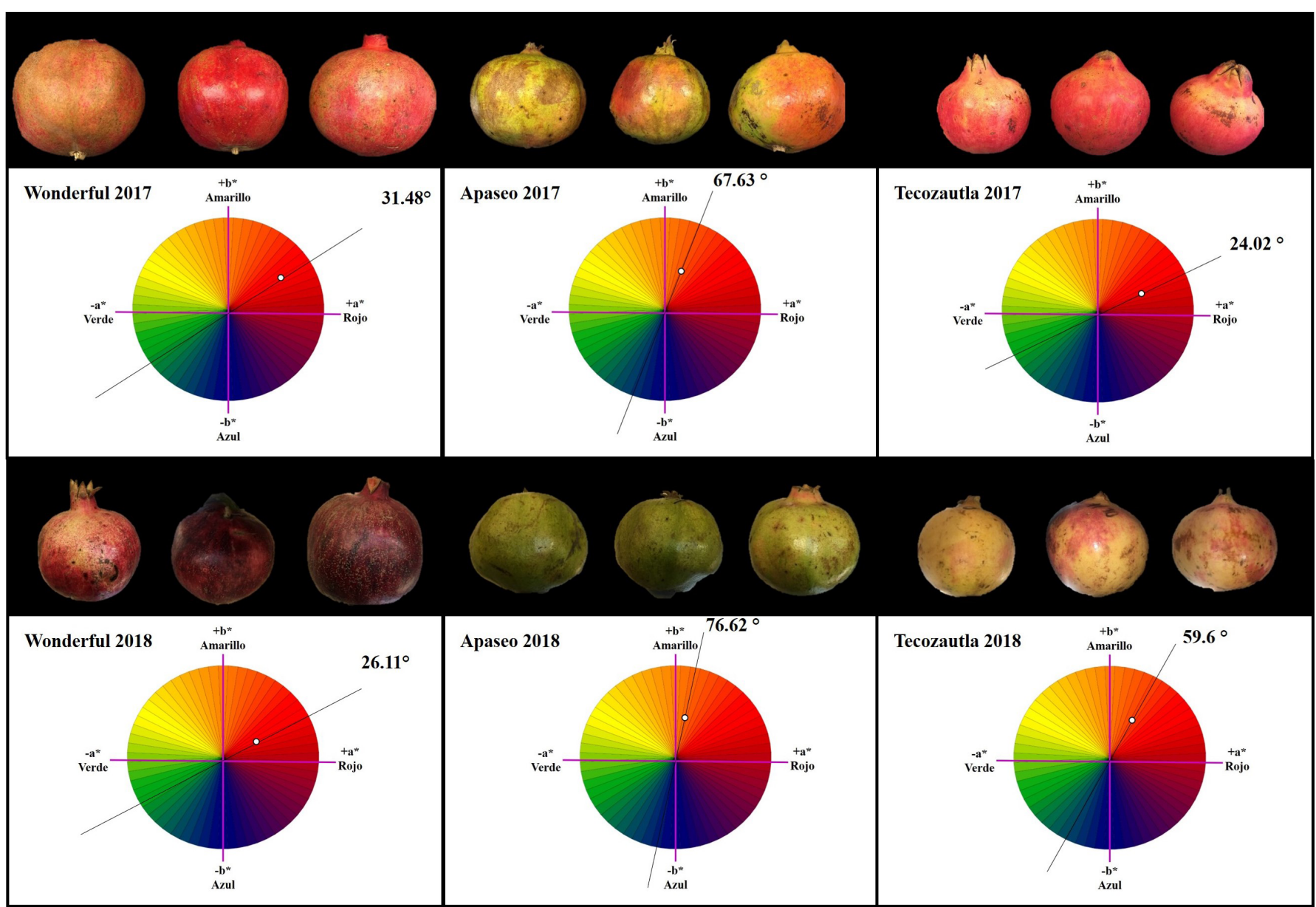

Figure 1. Peel colour of different mexican pomegranate varieties (P. granatum). 
Table 4. Physicochemical caracterization on juice of different mexican pomegranate varieties (P. granatum). The data analized have a significance value $(\alpha)$ of 0.05 and are expressed as the mean \pm standard deviation, $n=10$.

\begin{tabular}{|c|c|c|c|c|c|c|}
\hline \multirow{2}{*}{ Variety } & \multicolumn{2}{|c|}{$\mathrm{pH}$} & \multicolumn{2}{|c|}{ Total soluble solids ( $\left.{ }^{\circ} \mathrm{Brix}\right)$} & \multicolumn{2}{|c|}{ Citric acid $(\mathrm{mg} / \mathrm{mL})$} \\
\hline & 2017 harvest & 2018 harvest & 2017 harvest & 2018 harvest & 2017 harvest & 2018 harvest \\
\hline Wonderful & $1.17 \pm 0.23 b$ & $3.18 \pm 0.55 \mathrm{a}$ & $16.84 \pm 0.14 \mathrm{a}$ & $17.69 \pm 0.92 \mathrm{a}$ & $0.19 \pm 0.05 \mathrm{a}$ & $0.13 \pm 0.053 \mathrm{a}$ \\
\hline Apaseo & $1.37 \pm 0.08 \mathrm{~b}$ & $3.05 \pm 0.63 \mathrm{a}$ & $14.93 \pm 0.57 \mathrm{~b}$ & $13.75 \pm 1.48 \mathrm{~b}$ & $0.04 \pm 0.002 \mathrm{a}$ & $0.04 \pm 0.005 \mathrm{a}$ \\
\hline Tecozautla & $3.37 \pm 0.06 \mathrm{a}$ & $3.38 \pm 0.29 b$ & $14.86 \pm 0.33 \mathrm{a}$ & $16.96 \pm 0.62 \mathrm{a}$ & $0.31 \pm 0.05 \mathrm{a}$ & $0.05 \pm 0.043 \mathrm{a}$ \\
\hline
\end{tabular}

The $\mathrm{a}$ and $\mathrm{b}$ values are similarities between medias medias analized.

Regarding the total soluble solids in the 2017 harvest (Table 4), the concentration was; Wonderful $16.8 \pm 0.14^{\circ} \mathrm{Brix}$, Apaseo $14.8 \pm 0.5^{\circ} \mathrm{Brix}$ and Tecozautla was $14.8 \pm 0.33^{\circ} \mathrm{Brix}$ where compared with other cultivars the parameter is close. For 2018 harvest the concentration was; Wonderful $17.6 \pm 0.92^{\circ} \mathrm{Brix}$, Apaseo of $13.6 \pm 1.4^{\circ}$ Brix and Tecozautla was $17 \pm 0.62^{\circ}$ Brix. Regardind the total soluble solids has been observed that the concentration of total soluble solids in the fruit juice increases as the fruit develops, which could be verified since the Tecozautla variety was preliminary analyzed in a green state and was the one with the least amount. The existence or synthesis of a greater amount of soluble solids in fruit juices can be explained since in mature varieties there is a hydrolysis of starches that are transformed into sugars, as well as a decrease in tannins and other products causes astringent taste due to the decrease in acidity due to the degradation of organic acids.

Therefore, the variation of soluble solids by the conversion of starch into sugars is attributed to an increase in the activity of starch hydrolase enzymes (Álvarez-Herrera et al., 2009). The stage of the fruits, in comparation with other were proxim, so they can be considered ripe fruits (Mercado et al., 2011). On the other hand, it can be seen that the Apaseo variety analyzed has a lower degree of total soluble solids compared to that reported by Mercado et al. in 2011, which is due to the fact that the maturation time was shorter in the 2017 and 2018 harvests. In the case of the Tecozautla 2017 variety, it is possible to note that the amount of solids is less, since the variety had small dimensions and therefore there was less hydrolysis of the wall and sugar synthesis. In the Tecozautla variety of 2018 and in the Wonderful variety of both years, the values are within what is reported. Finally, the difference between compounds dissolved in pomegranate juices is due to a phenomenon known as the dilution effect due to the increase in the constituent elements of plant matter, so as the fruit matures and grows, the content of compounds decreases (Rendiles et al., 2004).

The observations on $\mathrm{pH}$ in the juice fruit were differents where a decrease in $\mathrm{pH}$ is seen, may be due to the increase of free organic acids in the fruit (Laguado et al., 1999). On the other hand, when there is an increase in the $\mathrm{pH}$ in a fruit but with a difference in ripening time, what happens is that during the filling of fruits a large part of the accumulation activity is given by symport, where the $\mathrm{H}^{+}$ions perform an important paper; these are part of the formation of substrates such as sucrose and glucose, and make their concentration at the vacuolar level decrease during the last stages of maturation, so the $\mathrm{pH}$ is slightly increased (Álvarez-Herrera et al., 2009).

\subsection{Polyphenols determination}

Once the pomegranates were characterized, the peel was dried in an electric oven at a temperature of $55^{\circ} \mathrm{C}$ for a time of $36 \mathrm{~h}$ to subsequently extract the polyphenols present by liquid-solid method with different solvents (ethanol and acetone), where it can be seen that the extraction of the metabolites could be carried out with both solvents and that this unit operation did not gradually affect the presence of these compounds since the highest concentration was obtained in those extracts where it was used acetone as solvents, being for the 2018 harvest a concentration of 0.2675 in gallic acid equivalents $\mathrm{mg} / \mathrm{mL}, 0.5122 \mathrm{EAG} \mathrm{mg} / \mathrm{mL}$ and $0.3347 \mathrm{EAG} \mathrm{mg/mL} \mathrm{for} \mathrm{Wonderful,} \mathrm{Apaseo} \mathrm{and} \mathrm{Tecozautla}$ respectively, so it can be seen that the conditions of Working proposals were favorable when working with the extracts at a concentration of $0.05 \mathrm{~g} / \mathrm{mL}$ in the extracts. For the ethanol extracts there was a concentration of $0.1524 \mathrm{EAG} \mathrm{mg} / \mathrm{mL}$, $0.2481 \mathrm{EAG} \mathrm{mg} / \mathrm{mL}$ and $0.1452 \mathrm{EAG} \mathrm{mg} / \mathrm{mL}$ respectively for the Wonderful, Apaseo and Tecozautla varieties, so it can be seen that high extraction temperatures, such as in the case of ethanol, they have a direct effect on the degradation and extraction of this type of compound, so when using acetone the yield was higher since the temperature worked was lower.

In previous works where the pomegranate has been taken as a study model, the one carried out, where they evaluated the physicochemical changes of the pomegranate variety "Rabbab-e-Fars" during its ripening process and observed a concentration after 20,80 and 140 days of the fruit set of 19.38 acid equivalents gallic $\mathrm{mg} / \mathrm{g}$ of juice, 12.98 gallic acid equivalents $\mathrm{mg} / \mathrm{g}$ of juice and 7.86 EAG $\mathrm{mg} / \mathrm{g}$ of juice respectively, observing a decrease in concentration as the fruit matures (Zarei et al., 2011). This change is due to the activation of the polyphenoloxidase enzyme, so this parameter allows us to know and standardize the ripening time of the fruits. The results obtained and expressed in the same units with the varieties worked with acetone as solvent were $5.35 \mathrm{EAG} \mathrm{mg/g} \mathrm{of} \mathrm{dry} \mathrm{extract,} 11.81 \mathrm{EAG} \mathrm{mg/g} \mathrm{of} \mathrm{dry} \mathrm{extract}$ and $6.69 \mathrm{EAG} \mathrm{mg/g}$ of dry extract for the Wonderful, Apaseo varieties and Tecozautla respectively, which indicates that the growth conditions provided by Mexico for the pomegranate are favorable to generate concentrations of polyphenols close to or higher, as in the case of the Apaseo variety, in the pomegranate peels compared to the juice of this variety analyzed since, based on the physicochemical analysis, it was deduced that the ripening time of the fruit was around 140 days after the fruit was tied and a comparison could be made. Talking about the ethanolic extracts, they had a concentration of $3.05 \mathrm{EAG} \mathrm{mg/g}$ of dry extract, 4.87 EAG mg/g of dry extract and 2.9 EAG 
$\mathrm{mg} / \mathrm{g}$ of dry extract for the Wonderful, Apaseo and Tecozautla varieties respectively, therefore, if worked with this solvent, it would also allow obtaining significant amounts of extractable polyphenols. Investigations in 2013 where an analysis about of the secondary metabolites in the fruit of pomegranate was made, mentioning polyphenols with a significant presence, as well as a positive presence of tannins, flavonoids, mucilages, saponins, terpenes and glycosides, however, at making the alkaloid determination, the response was negative, so it would be important to perform a characterization of the secondary metabolites present in the ketone and ethanolic extracts of the peels of Mexican pomegranates to know which of them are in greater proportion (Chebaibi \& Filali Rhazi, 2013).

\section{Conclusions}

The varieties of pomegranates in Mexico are wide and very diverse, so with this analysis in three varieties it can be concluded that they are different in terms of the physiological parameters measured such as: weight, dimensions, hardness and colour, as well as in their chemical parameters such as: total soluble solids and $\mathrm{pH}$ in the fruit juice, which is due both to the genetic variability of each variety as well as to the growing conditions that have a significant effect on the pomegranates.

On the other hand, it can be concluded that the morphological characteristics of the pomegranate fruit can serve to establish the ripening stage of the fruit, provided that they are of the same variety, and with these parameters, it is possible to determine in what time of growth they can have fruits with physical and chemical characteristics desirable for the consumer and, above all, have chemical compounds in high concentrations when reaching the desired ripening, such as polyphenols, that increase their concentration as the fruit reaches its full maturity. Finally, with the determination of polyphenols evaluated, it can be concluded that the pomegranate contains significant amounts of these metabolites in its peel, so it can be used for the development of biotechnological products, giving added value to the fruit since this part of the fruit is only discarded during fruit processing.

\section{Acknowledgements}

We thank the partial donations to Convocatoria de Apoyo a la Investigación Científica y Tecnológica 2019 (5096.19-P). Project: Optimización en la extracción de polifenoles con actividad antioxidante en variedades mexicanas de granada (Punica granatum), Tecnológico Nacional de México/Instituto Tecnológico de Morelia. We also appreciate the participation of the "Consejo Nacional de Ciencia y Tecnología" (CONACyT) through the financial support of the scholarship 462005.

\section{References}

Al-Maiman, S., \& Ahmad, D. (2002). Changes in physical and chemical properties during pomegranate (Punica granatum $L$.) fruit maturation. Food Chemistry, 76(4), 437-441. http://dx.doi.org/10.1016/S0308-8146(01)00301-6.

Álvarez-Herrera, J., Galvís, J., \& Balanguera-López, H. (2009). Determinación de cambiosfísicos y químicos durante la maduración de frutos de champa (Campamonesia lineatifolia R.\& P.). Agronomia Colombiana, 27(2), 253-259.
Brummell, D. A., Dal Cin, V., Crisosto, C., \& Labavitch, J. (2004). Cell wall metabolism during maturation, ripening and senescence of peach fruit. Journal of Experimental Botany, 55(405), 2029-2039. http://dx.doi.org/10.1093/jxb/erh227. PMid:15286150.

Chebaibi, A., \& Filali Rhazi, F. (2013). Bactericidal activity and phytochemical screening of Moroccan pomegranate (Punica granatum Linn.) peel aqueous extracts. Journal of Medicinal Plants Research, 7, 887-891.

Díaz, L. (2009). Interacciones moleculares entre plantas y microorganismos: saponinas como defensas químicas de las plantas y su tolerancia a los microorganismos. Una revisión. Revista de Estudios Transdisciplinarios, 1(2), 32-54.

Laguado, N., Pérez, E., Alvarado, C., \& Marín, M. (1999). Physicalchemical and physiologycal characteristics of guava fruits of Criolla Roja and San Miguel types from two comercial plantations. Facultad de Agronomía, 16, 382-397.

López-Mejía, O., López-Malo, A., \& Palou, E. (2010). Granada (Punica granatum $L$ ): una fuente de antioxidantes de interés actual. Temas Selectos de ingeniería de Alimentos, 4(1), 64-73.

López-Rubira, V., Artés-Hernández, F., \& Artés, F. (2017). Repositorio Digital de la Universidad Politécnica de Cartagena. Cartagena: CRAI Biblioteca/Universidad Politécnica de Cartagena.

Mercado, E., Mondragón, C., Rocha, L., \& Álvarez, B. (2011). Effects of fruit condition and storage temperature on pomegranate quality. Revista Mexicana de Ciencias Agrícolas, 2, 449-459.

Rendiles, E., Marín L., M., Castro de R., C., \& Ferrer M., O. (2004). Variación en la concentración foliar del guayabo (Psidium guajava L.) y su relación con el rendimiento del cultivo. Revista de la Facultad de Agronomía, 21(1), 78-88.

Sai, C., \& Prakash, I. (2011). bioactive chemical constituents from Pomegranate (Punica granatum) juice, seed and peel-a review. International Journal of Research in Chemistry and Environment, 1(1), 1-18.

Sanchez, M., Pena, M., Revilla, G., \& Zarra, I. (1996). Changes in dehydrodiferulic acids and peroxidase activity against ferulic acid associated with cell walls during growth of Pinus pinaster hypocotyl. Plant Physiology, 111(3), 941-946. http://dx.doi.org/10.1104/ pp.111.3.941. PMid:12226339.

Sarkhosh, A., Zamani, Z., Fatahi, R., \& Ebadi, A. (2006). RAPD markers reveal polymorphism among some Iranian pomegranate (Punica granatum L.) genotypes. Scientia Horticulturae, 111(1), 24-29. http:// dx.doi.org/10.1016/j.scienta.2006.07.033.

Sepúlveda-Jiménez, G. (2003). La participación de los metabolitos secundarios en la defensa de las plantas. Revista Mexicana de Fitopatología, 21(3), 355-362.

Servicio de Información Agroalimentaria y Pesquera - SIAP (2017). Estadísticas de granada en México. Ciudad de México: Blog Agricultura. Retrieved from https://blogagricultura.com/estadisticas-granada-mexico/

Tezcan, F., Gültekin-Özgüven, M., Diken, T., Özçelik, B., \& Erim, F. B. (2009). Antioxidant activity and total phenolic, organic acid and sugar content in commercial pomegranate juices. Food Chemistry, 115(3), 873-877. http://dx.doi.org/10.1016/j.foodchem.2008.12.103.

Vilela, A., González-Paleo, L., \& Ravetta, D. (2011). Metabolismo secundario de plantas leñosas de zonas áridas: mecanismos de producción, funciones y posibilidades de aprovechamiento. Ecología Austral, 21, 317-327.

Viuda-Martos, M., Fernández-López, J., \& Pérez-Álvarez, J. (2010). Pomegranate and its many functional components as related to human health: a review. Comprehensive Reviews in Food Science and Food Safety, 9(6), 635-654. http://dx.doi.org/10.1111/j.1541-4337.2010.00131.x. 
Yasoubi, P., Barzegar, M., Sahari, M., \& Azizi, M. (2007). Total phenolic contents and antioxidant activity of pomegranate (Punica granatum L.) peel extracts. Journal of Agricultural Science and Technology, 9, 35-42.
Zarei, M., Azizi, M., \& Bashir-Sadr, Z. (2011). Evaluation of physicochemical characteristics of pomegranate (Punica granatum L.) fruit during ripening. Fruits, 66(2), 121-129. http://dx.doi. org/10.1051/fruits/2011021.' 